\title{
THE USAGE OF ANIMALS IN THE LIVES OF THE LANOH AND TEMIAR TRIBES OF LENGGONG, PERAK
}

\author{
Fatan Hamamah Yahaya \\ School of Distance Education \\ Universiti Sains Malaysia \\ 11800 Penang \\ hamamah@usm.my
}

\begin{abstract}
In Malaysia, the Orang Asli communities are natives that comprise the Negrito, Senoi and Proto-Malay peoples. Traditionally, the Orang Asli live in isolated forests or in forest peripheries. Although Globalisation occurs in Malaysia, its occurrence does not affect the traditional values of the said Orang Asli, who still depend on the natural environment to live. Nature provides the Orang Asli with a community resource for acquiring animals that are not just consumed as food, but also used in medicine, hunting and myth creation. This study intends to identify the animal species and the methods the Senoi and Negrito use these animals, within the aspects of their diet, medicine, hunting methods and their myth creation. Empirical data collection is focused only on the Lanoh and Temiar tribes who live in Lenggong. The method of data collection involves in-depth interviews with key informants that comprise Tok Batins (tribal chiefs) and focus groups from the chosen Orang Asli village communities in Kampung Air Bah and Kampung Lubuk Chupak, Lenggong. The findings of this study reveal a wide variety of animals are still being hunted by the Orang Asli community for food and medicine. Apart from that, there are specific beliefs regarding the animals hunted narrated through myths and legends. Therefore, this study is significant in order to determine that the animal usage in the lives of the Orang Asli community continue for the sake of the demands of their heritage and families in order to preserve its pristine continuity. This is because while findings show that wildlife is still used by the Orang Asli, their usage among the younger generation is increasingly eroded due to such factors as wildlife extinction, dwindling availability, new religious taboos and modern progress which continues to find its place within the Orang Asli community.
\end{abstract}

Keywords: Orang Asli, animal usage, Lanoh, Temiar

\section{INTRODUCTION}

Generally, fauna is used as a food source, as a pet's source and as transportation in times of old. However, in the Orang Asli communities of Malaysia, animals are not merely utilised as a food source, but also as a source of medicinal applications, as well as source material for folktales and myths. It demonstrates that the lives of the Orang Asli are tightly connected to the elements of nature, particularly to flora. Indeed, these elements of nature are interpreted as direct links between the realm of man and the cosmos. It is this belief system that marks them out as unique from the other races within the country (Malays, Indians and Chinese). The Negrito and Senoi form the most populous tribes in Perak, but not all Negritos and Senois live in Perak, as there are only five tribal groups living in the state. Negrito groups include the Kintak, Jahai and Lanoh tribes, and the Temiar and the Semai, among the Semai groups (Suki, M. 2009)

The Lanoh and Temiar live mostly within the remote areas of the Hulu Perak district, such as Lenggong. Apart from being known for the Lenggong Valley Archaeology Site, especially after its ratification as a World Heritage Site by the United Nations Educational, Scientific and Cultural 
Organization (UNESCO) on 30th June 2012 (Hassan, F. et all, 2013), Lenggong is also the home the home to the Lanoh and Temiar Orang Asli communities. Before they lived here, the Orang Asli community lived as nomadic explorers, hunters and gatherers of forest produce, while living in particular place as long as the produce acquired could fulfil the living requirements of their community, before moving to another area (Nicholas, C.,2000). However, ever since the Malaysian government began to focus on public welfare, they have now been giving a village compound and currently live there (JAKOA, 2013). The village compound of the Lanoh and Temiar communities are close to the forest, resulting in their continued reliance on the natural environment for income, employment, food, medicine and religious purposes.

\section{LITERATURE REVIEW}

The Orang Asli community of Malaysia continues to gain attention in terms of research within the academic community, social scientists, development planners and the government in general. This research comprises many fields, including Anthropology, History, Geography and Economics. This was made evident when a variety of research was done on the Orang Asli, amongst which related to their usage of fauna by their community. The earliest research done on fauna usage was done by Lim, K.H (1900), who studied the usage of animals in regards to pre-natal dietary taboos amongst the women of the Semai and Temuan Orang Asli tribes.

Apart from Lim, K.H. (1900), fauna usage in terms of taboos and habits was also studied by Mahadzir, S. (2007), who found that monkeys and fish were still consumed the dietary habits of the Orang Asli. Other research concerning the use of fauna in diets found that fish forms the main protein source of the Orang Asli community (Ali, O. et al. 1991; Alias, I.Z., 1999; Low, A.C., 2000; Sok, K. M., 2000). However, Ali, O. et al. (1991), found that the consumption of other forms of seafood, such as squid and cockles are rarely consumed by the Orang Asli. Apart from sea animals, land animals such as chickens, deer, boars and rabbits are also consumed as primary protein sources (Low, A.C., 2000; Sok, K.M., 2000: Ali, O., and Isa, Z.M., 2005). Usually, the Orang Asli use animals for food, although the research findings of Ali, O., and Isa, Z.M., (2005) also find chickens and goats are also kept as pets, while the research findings of Er, A.C et al. (2010) at Bukit Langgong observe the Orang Asli community living there use these animals as a source of income. This is a marked difference from the Semai Orang Asli community in Who Rapah, that used elephants as a mode of transport to carry rattan and tin ore back in the past (Suki, M., 2009).

Animals are also used in medicine, to treat illnesses encountered by the Orang Asli community at a certain village (Lim, 1900; Juli, 1988). Among the animals used in medicine by the Semai and Temuna include pythons, crab-eating macaques, birds, rhinos, pig-tailed macaques and monitor lizards (Lim, K.H. 1900). Among the Malays, fables of The Mousedeer as well as The Tortoise and the Hare are quite popular, but among the Orang Asli of Kampung Air Bah and Lubuk Chupak, there is a wide plethora of animals in the fables of its society. The fables of the Orang Asli have been studied by Lim, B.L. (1981; 1984), who found that while there are small differences between the fables in each Orang Asli community in every Malaysian state, they are fundamentally similar in theme.

\section{RESEARCH SCOPE AND METHOD}

The research done involves the Orang Asli communities of the Lanoh and Temiar who live in Kampung Air Bah and Lubuk Chupak, situated in the Lenggong district, Perak and borders the district of Kuala Kangsar and Gerik (JAKOA Perak, 2012). The community of Orang Asli in Kampung Air Bah numbers 227 people, living in 42 houses (both traditional and brick houses) while the community in KampungLubukChupak number 126 people living in an area 20.234 square kilometres wide (JAKOA 
Perak, 2012). Prior to this, Kampung Air Bah was inhabited by a community of Lanoh while the only the Temiars lived in Lubuk Chupak. However, due to inter-marrying, the Lanoh tribe and Temiar now both live in both of the villages.

Research data was acquired via in-depth an interview with a "key-informant", that is an individual who is knowledgeable and experienced within a particular community given a set of interview questions. The interview method is in line with a method utilised by Robson, C. (1993), which is research data acquired from inquiries, observations and interviews. These research interviews involve "key informants", one from Kampung Air Bah, who is a 'Tok Batin' or a village head (Alias bin Semedang), while in KampungLubukChupak the key informant is also a Tok Batin (Anjang bin Alim), as well as Win bin Ali, the head of the Village Development Committee (Jawatan Kuasa Kemajuan Kampung, JKKK). Apart from community leaders, interviews were also held with focus groups, made of Orang Asli community members gathered into small for the purpose of being interviewed. The interviews were then recorded on audio-tape, to enable unlimited replays of the interviews, in order to facilitate the researcher's analysis of the research findings in the form of a report. The qualitative research findings were then analysed using content analysis.

\section{RESEARCH FINDINGS}

Respondent Profile

Analysis results found as many as 61 Orang Asli have involved themselves in this study via interviews that have been carried out, and out of that total 24 people (39.3\%) are male while the rest $(60.9 \%)$ are female (Schedule 1). All respondents are above 20 years of age, and the majority are between the ages of $36-50(59 \%)$, the rest being $34.4 \%$ of the respondents aged $20-35$ years old and only 4 people $(6.6 \%)$ being respondents aged 50 years and above. It shows that the respondents are already matured in the way that they answer the questions, even though most of the respondents do not have a formal educational background (schooling). Out of the 61 that were interviewed, the majority are from the Temiar (63.9\%), while the rest $(36.1 \%)$ are from the Lanoh tribe (Schedule 1). Although they hail from different tribes, all respondents are Muslims. Due to their close proximity with the forest, the occupations of the male respondents include farming, rubber tapping and collecting forest products, although there are female rubber tappers even though most of them are full-time housewives.

\section{The Usage of Animals in Diets}

The Orang Asli's usage of animals as a food source can be observed through their main protein source, which is fish. The findings confirm the research done by Ali, O. et al. (1991), Alias, I.Z. (1999), Low, A.C. (2000) and Sok, K.M. (2000), who find that fish is the main protein source. The fish that the Orang Asli community consume are caught from rivers using their hands, fish-cages, nets, javelins and homemade fishing rods. This differs from the research findings of Yusof, A.H. (1993), who states that Orang Asli use fish-traps, fishing lines, "tuba root" poison (extract of the Derris plant), spears as well as nets to catch fish. Apart from fish, they also catch wild jungle fowl using snares. According to the informants, "upper" animals (arboreal wildlife), such as monkeys, squirrels and birds are caught using blowpipes. Apart from blowpipes, birds are also caught using slingshots, while pangolins are caught with spears. These methods of hunting differ somewhat from the native societies of Sarawak's interior, that largely favour rifles for hunting (Ngah, M.A., 20 Jun 2006). The game and fish caught by the Orang Asli living in Kampung Air Bah and Lubuk Chupak are then cooked in the traditional manner, inside bamboo casks. According to the Orang Asli, roasting or grilling maintains the flavour of the meat while eliminating any overt fishiness in the fish or off-tastes in game. However, wild fowl cannot be cooked over a fire because it becomes too tough to eat. 
Even though they eat a wide variety of foods, a majority of the respondents do not know of the nutritional value that their animal-based diet contains. This may have something to do with theeducational attrition rate amongst the Orang Asli community (Mat, N.H., 2000). Interestingly, they do not consume animals that they raise (which include chickens, ducks, cats and dogs) because of their affection towards them, and their belief that these animals return all of their affection towards those that rear them (Bolton, J., 1972; Ali, O., dan Isa, Z.M., 2005). It is thus evident that the dietary habits of the Temiar and Lanoh Orang Asli tribes do not differ very much, but a marked difference in animal consumption and usage can be seen in their dietary taboos.

The Temiar and Lanoh Orang Asli communities in Kampung Air Bah and Lubuh Chupak still maintain their taboos even though they have converted to Islam, although they do in fact hold on to their beliefs in supernatural forces. For the Temiar, they are forbidden from eating wild boar, snakes and squirrles because they are considered unclean animals, while the Lanoh do not eat legless crawling animals, such as snakes. Animals such as tigers, elephants, barking deer, sambar deer, chickens and fish cannot be eaten by expecting mothers of the Temiar. These findings support the research of Bolton, J. (1972), which find that Orang Asli do not eat tigers because they are said to possess the spirit of humans and eat humans as well. This differs from the dietary taboo of the Lanoh of LubukChupak, because their expecting women do not eat barking deer, sambar deer, squirrels, mouse-deer, chicken and lutungs, while only hand-caught fish is ever allowed.

In spite of it all, research findings in an isolated Orang Asli reserve village found that these strict taboos do not affect the health levels of the mothers or their children (Rahimi, H., et al., 2003). The parents of Lanoh descent also refrain from eating barking deer, sambar deer, lutung, pig-tailed macaques and siamangs, to avoid the baby from developing seizures.It can be the said that dietary taboos among the Orang Asli community are closely related to the spirit that is possessed by a certain animal, to the point where these animals are considered dirty, poisonous and inedible while fearful of the negative effects that entail eating such animals (Ali, O., and Isa, Z.M., 2005). As a result, research on the effects of the Orang Asli diet are important because according to Salleh, M.J. et al. (2009), diet is a factor that influences the Orang Asli's level of education, because a good nutritious diet positively influences mental activity.

The Usage of Animals in Medicine

Even though the Orang Asli community already uses modern medicine, they still practice traditional ways to cure certain diseases, but only certain animals can be used because they rely more on herbal foliage (flora). The Temiar and Lanoh tribes that live in Kampung Air Bah and KampungLubukChupak eat python meat to remove excess body heat, in order to "cool" the body. This finding supports the research results of Lim, K.H. (1900), that found that Semai Orang Asli in Air Denak use python to treat general ailments.

This differs somewhat from the Semai in Kampung Jantung Baru, Perak who use the consumption of bear hearts to eliminate excess body heat, while for the same results the Semai of Sungai Ruil in Pahang eat woodworms. According to the Temiar of Air Bah, rabbit meat is believed to be effective in rejuvenating and revitalising the body. Malays use the snakehead fish to heal internal wounds suffered by post-natal women, and this is also the case with the Temiar. However, this age-old tradition is in decline because many women now give birth in maternity hospitals which use modern medicines supplied by the hospitals, apart from the fact that snakeheads are actually hard to come by in Air Bah. This differs from the research of Yusof, J. (tt), which states finding the shamanistic healing methods of the Semai of Tapah, Perak that use "sewang" dances, incantations, and the rites of 'tenghir', 'berkebut' and 'sangkak', which are medicinal treatments that call upon supernatural forces. 


\section{The Usage of Animals in Folktales}

Folktales and myths amongst the Temiar and Lanoh Orang Asli communities in Kampung Air Bah and Lubuk Chupak involve animals such as elephants, pangolins and tigers. Even though the fables of the elephant and pangolin told by the Orang Asli is not very widespread, it shares some similarities with stories that were once written by Lim, B.L. $(1981,1984)$, a fable about an elephant that died because of a pangolin. Based on this fable, many among the Orang Asli believe that the pangolin actually killed the elephant and that it has supernatural powers. As a result, there are many in the Orang Asli community that wear pangolin scales to ward off evil spirits. Apart from that, there are those that believe that pangolin meat possesses numerous nutrients and is medicinal (Lim, K.H., 1900). According to one respondent, the scales of the pangolin are burned and kept indoors to ward off elephants which come into the reserve, because burnt pangolin scales have an extremely strong smell, as well as because of the fable that stated the elephant was killed by a pangolin.

According to one Temiar respondent, the tiger is considered their ancestor and is believed to have a supernatural spirit, capable of bestowing knowledge upon their tribe. As a result, whenever they encounter a tiger, even though they are wounded and bloody, the tiger do not eat or harass the Temiar. This is in contrast to the narrative of a Lanoh respondent, who states that if they have a bloody wound and the tiger catches a whiff of it, they will surely become its prey. Apart from that, fables about tigers are also connected to the dream beliefs of the Temiar of Kampung Air Bah. This is because, if a person dreams of a tiger giving its fangs to him or her, it would be best not to wander off anywhere, because they believe that they will meet with a tiger, but will be left unharmed.

Apart from tigers, snakes are also related to the dream beliefs of the Orang Asli. When they dream of a beautiful woman, it is a sign that they will encounter a snake, which indicates that the beautiful woman is the altered form of a snake. There are also inhabitants of the community that dream of snakes that desire to give stones which will heal the ailment according to the demands of the stone's possessor. However, not all respondents know of these fables, especially teenagers and adults (20-50 years of age) because according to them, the elderly never told them the fables of the Orang Asli community.

\section{CONCLUSION}

The Orang Asli community of Lenggong still utilize animals in their diet, medicine and storytelling. This research shows that there is little difference in the dietary polarities of the Temiar and the Lanoh, although the differences can be seen in the utilisation of animalsin medicine and fable creation. However, there are few findings on the usage of animals in medicine and fable creation because the majority of the respondents do not know of the usages of animals to cure disease and that there are fables about their native animals in the Orang Asli community. Even so, the utilisation methods of animals in traditional medicine need to be studied by the relevant authorities in order to determine the efficacy of certain animals in treating certain diseases, so that they can be commercialised.

The uniqueness of the traditional animal utilisations in diet and folktales should be preserved so that its continuity can be passed on to future generations. This study is important in order to determine that the uniqueness of animal utilisation and diet, medicine and storytelling will still be maintained and known by the Temiar and Lanoh Orang Asli communities of Lenggong. Therefore, more studies are needed in order to determine these discoveries and consequently determine the continuity of animal utilisation in diets, medicine and folktales, or in other aspects that are still practised by the Orang Asli communities of Malaysia. 


\section{REFERENCES:}

Ali, O., dan Isa, Z.M., 2005. Kehidupan dan Kesihatan Orang Asli di Malaysia. Sabah: Universiti Malaysia Sabah.

Ali, O., Shamsudin, Z., dan Khalid, B.A.K., 1991.A Socioeconomics, Social Behaviour, and Dietary Pattern among Malaysian Aborigines and Rural Native Malays.Med. J. Malaysia. Vol.46. 3 September 1991.

Alias, I.Z., 1999. The Supplementation of Lerothyroyine among Indigenous People in Endemic Goitre Areas: The Impact of the Rcpy. Asia Pasific Journal of Clinical Nutrition.7 (2): 1-3.

Bolton, J. 1972. Food Taboos among the Orang Asli in West Malaya: A Potential Nutrition Hazard. Amer J. Clinical Nutrition, 25:789-799.

Edo, J., 1922. Agama dan Perubata nMasyarakat Semai. Bangi: Faculty of Social Science and Humanities.

Er, A.C., Ariffin, Z.C.C.M., dan Pereira, J.J., 2010. Sosio ekonomi Masyarakat Orang Asli: Kajian Kes di HutanSimpan Bukit Lagong, Selangor, Malaysia. JurnalMelayu (5) 2010: 295-314.

Hassan, F., Zakaria, Z., Abdul, H.N., Rindam, M., dan Hamamah, F., 2013.Peningkatan Daya Saing Lembah Lenggong Berasaskan Pelancongan Sumber Setempat.GEOGRAFIA OnlineTM Malaysian Journal of Society and Space 9 Issue (35-49).

JAKOA (JabatanKemajuan Orang Asli).2013. Suku Kaum/ Bangsa. http://www.jakoa.gov.my/web/ guest/suku-kaum/bangsa. Diakses pada: 4 Jun 2013.

JAKOA Perak, 2012.Masyarakat Orang Asli di Lenggong. Perak: Jabatan Kemajuan Orang Asli, Lenggong.

Lim, K.H., 1900. Pemakanan Orang Asli: Suatu Penyelidikan Empat Kampung Semai dan Temuan. Kuala Lumpur: Dewan Bahasa dan Pustaka.

Lim, B.L. 1984. Kisah-kisah Haiwan Orang Asli. Selangor: Eastern Universitees Press (M) Sdn. Bhd.

Lim, B.L., 1981. Orang Asli Animal Tales. Kuala Lumur: Eastern Universitees Press (M) Sdn. Bhd.

Low, A.C., 2000. Penilaian Taraf Pemakanan Warga Tua Semelai di Kampung Sungai Sampo, Jempol. B.S. Graduation Exercise. UPM: Department of Nutrition and Health Science Faculty of Medicine and Health Science.

Mahadzir, S., 2007.Adat Resam Masyarakat Orang Asli. Selagor: Cooray's House of Publications Sdn. Bhd.

Mat, N.H, 2000.Pendidikan dan Masa Depan Komuniti Orang Asli. Dalam Aziz, R.A., dan Ismail, M.Y. Masyarakat, Budaya dan Perubahan. Bangi: Penerbit UKM.

Ngah, M.A., 20 Jun 2010. 9 Jerat WarisanJakun.http://www.bharian.com.my/bharian/articles/ 9jeratwarisanJakun/Article.Diaksespada: 4 Jun 2013.

Nicholas, C. 2000. The Orang Asli and the Contest for Resources: Indigenous Politics, Development and Identity in Penisular Malaysia. Kuala Lumpur: Vinlin Press Sdn. Bhd.

Rahimi, H., Fatimah, A.M., Rahimah, I., Sarah, Y., dan Marlia, M.S., 2003. Adakah Pantang Larang Pemakanan di Kalangan Orang Asli Mempengaruhi Tahap Kesihatan lbu dan Anak: Pengalaman Daerah Kuala Lipis. Malaysia Journal of Public Health Medicine.Vol.3 (1): 73-77.

Robson, C., 1993. Real World Research: A Resource for Social Scientist and Practitioner Researchers. Oxford: Blackwell.

Salleh, M.J., Idris, N.K., Aziz, N.A.A., Yusuf, N.H., dan Hashim, S.A., 2009. Kajian Terhadap Kesedaran Pendidikan di Kalangan Masyarakat Orang Asli. Persidangan Kebangsaan Pendidikan Luar Bandar. Sabah: Universiti Malaysia Sabah.

Sok, K.M., 2003. Latar Belakang Sosio-Ekonomi dan Taraf Pemakanan Orang Asli Lelaki Desa di Sungai Sampo.Serdang: Universiti Putra Malaysia.

Suki, M., 2009.Orang Asli Perak: Perayaan Jis Pai dan Adat Perkahwinan. Ipoh: Yayasan Orang Asli Perak. 
Yusof, A.H., 1993. Seni dan Kraf Orang-Orang Asli. Selangor: Universiti Teknologi Mara.

Yusof, J., tt. Perubatan Tradisional: Upacara Tradisional dan Pantang Larang Komuniti Semai di Daerah Batang Padang, Tapah, Perak. http://www.jakoa.gov.my/en/web/guest/abstrakkajian. Diakses pada: 25 Julai 2013

\section{ACKNOWLEDGEMENT}

The writer would like to thank Universiti Sains Malaysia for the Sustainable Tourism Cluster University Research Grant (Grant No. 1001/PTS/8660012) that helped made this study and paper possible. 